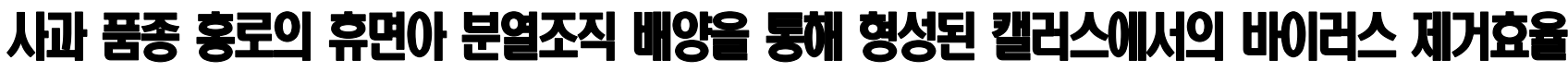

김미영 · 천재안 · 조강희 · 박서준 · 김세희 · 이한찬

\section{Efficiency of virus elimination in apple calli (cv. Hongro) derived from meristem culture of dormant buds}

\author{
Mi Young Kim - Jae An Chun $\cdot$ Kang Hee Cho Seo Jun Park $\cdot$ Se Hee Kim $\cdot$ Han Chan Lee
}

Received: 18 September 2017 / Revised: 17 October 2017 / Accepted: 23 October 2017

(C) Korean Society for Plant Biotechnology

\begin{abstract}
Various sizes $(0.2 \sim 1.2 \mathrm{~mm})$ and developmental stages (referred to as Stage 1 3) of apical and lateral meristems were excised, together or separately, directly from dormant buds of apple 'Hongro'. They were mixed infected by Apple scar skin viroid (ASSVd), Apple chlorotic leaf spot virus (ACLSV), Apple stem pitting virus (ASPV) and Apple stem grooving virus (ASGV), which are major viruses attacking apples. A total of 31 callus lines $(>10 \mathrm{~mm}$ in diameter) were obtained by culturing the explants on Murashige and Skoog (MS) medium supplemented with 3\% sucrose, $3.0 \mathrm{mg} / \mathrm{L}$ benzyladenine (BA) and $0.1 \mathrm{mg} / \mathrm{L}$ indole-3-butyric acid (IBA), and they were subjected to RT-PCR analysis for virus detection. A high rate of virus elimination (expressed as the percentage of calli that did not amplify during RT-PCR, i.e., RT-PCR negative calli per total number of calli obtained) was achieved for ACLSV (100\%), ASSVd (93.7\%), and ASPV (93.7\%), whereas it was only $25.8 \%$ for ASGV. ASPV was detected in the presence of $2 \sim 3$ bracts. Simultaneous virus elimination of ASSVd, ASPV, ACLSV, and ASGV occurred during the meristem culture, in which the early stages of the dormant buds (Stage 1) were used, because ASGV was mostly eliminated during that stage. The results of the present study will be valuable for the production of virus-free apple trees.
\end{abstract}

M. Y. Kim • J. A. Chun $\cdot$ K. H. Cho $\cdot$ S. J. Park $\cdot$ S. H. Kim $•$ H. C. Lee $(\square)$

농촌진흥청 국립원예특작과학원 과수과

(Fruit Research Division, National Institute of Horticultural and

Herbal Science, Rural Development Administration, Wanju

55365, Korea)

e-mail: 10hc0811@korea.kr
Keywords Tissue culture, Meristem excision, Apple tree, Virus detection, RT-PCR

서 언

사과는 세계적으로 가장 광범위 하게 재배되고 있는 과수 중의 하나로, 우리나라에서 대표적인 과수 작물이다. 사과 에 발생하는 주요 바이러스는 Apple chlorotic leaf spot virus (ACLSV), Apple stem pitting virus (ASPV), Apple stem grooving virus (ASGV)가 있으며, 이 세가지 바이러스는 일반적으로 재배 품종에서 직접적인 피해 증상은 잘 나타나지 않으나, 복합감염의 형태로 흔히 발생하며, 바이러스에 민감한 대목 에 고접병을 일으킬 수 있다(Hu et al. 2015; Paprstien et al. 2008). Apple scar skin viroid (ASSVd)는 바이로이드의 한 종류 로 중국과 일본에서 사과 품질에 심각한 피해를 끼치는 것으 로 보고되었으며(Chen et al. 1986; Ushirozawa et al. 1968), 우리 나라에서는 경북지역에서 사과품종 미끼라이프'에서 새로 운 분리계통으로 처음 진단된(Lee et al. 2001)이후, 주로 사과 의 과실에 특이적으로 증상이 나타나 착색불량, 과피얼룩 및 과중감소를 초래하여 과실의 품질을 저하시킨다고 하였 다(Kim et al. 2010; Kwon et al. 2002). 사과는 주로 접목에 의해 증식하는 영양체 번식 작물로서 이러한 바이러스에 일단 감 염되면, 세대를 이어 전염되고 방제가 전혀 되지 않는다. 따 라서, 사과에서 바이러스 무병주 생산은 필수적이며 세계적 으로 이를 위한 연구가 집중되고 있다.

사과에서의 바이러스 제거기술은 기내 또는 기외에서 식 물체를 열처리한(thermotherapy) 후, 경정배양(shoot-tip culture) 을 병행하는 방법이 주로 사용되었다(Lee et al. 2013; Paprstein et al. 2008). 또한, 항바이러스 약품(antiviral drugs)을 이용한 화학처리법(chemotherapy)(Hansen and Lane 1985; Hu et al. 
2015), 초저온보존 처리법(cryopreservation)(Li et al. 2016)등 이 보고되었다. 하지만, 기존의 바이러스 제거방법은 감염 식물체를 도입한 후 인위적인 무병화 처리를 시도한 것으로 처리과정에 따라 시간과 인력소모가 많은 편이다. 본 연구 진은 이러한 점을 해결하고 사과 바이러스 제거에 대한 새로 운 방법을 제시하고자, 바이러스에 감염된 동절기 휴면아 (측아)를 식물재료로 사용하여 본 연구실험을 수행하였다. 본 연구진이 착안한 점은 노지의 동절기 휴면아 속의 분열조 직은 식물체가 비 광합성 상태로 자연 조건 하에서 한냉처리 를 받은 것으로 간주할 수 있고, 따라서, 인위적인 무병화 처 리를 회피할 수 있다는 점을 염두에 둔 것이다. 본 실험의 내 용은 휴면아의 발달단계에 따라 분열 조직을 절취하여 캘러 스를 유도한 후 RT-PCR 분석을 통해 절취한 분열조직에서 감염되었던 바이러스가 제거되었는지를 조사한 것으로, 기 존에 보고되지 않은 내용이며, 바이러스 제거 방법에 대한 새로운 접근으로 향 후 사과의 무병묘 생산에 매우 유용한 자료로 활용될 수 있을 것이다.

\section{재료 및 방법}

식물 재료

본 연구실험에서는 농촌진흥청 국립원예특작과학원 연구 포장에 재식된 사과 '홍로' 식물체 중 ASSVd, ASPV, ACLSV, $\mathrm{ASGV}$ 의 4종 사과 바이러스 복합 감염을 확인한 \#7, \#8,\#11 (Fig. 1)의 동절기 휴면아를 식물재료로 사용하였다. 1월 말 경 각 식물체의 나뭇가지 끝부분을 약 $20 \sim 30 \mathrm{~cm}$ 길이로 잘 라 채취한 후(Fig. 2A), 측아 휴면아를 조직배양용 메스로 도 려내었다(Fig. 2B). 휴면아의 바깥부분 포엽(bracts)들을 제거
하고, 안쪽 포엽을 약 $3 \sim 4 \mathrm{~mm}$ 의 길이로 남긴 후, $70 \%$ 에탄올 에 침지하여 약 40 초간 표면살균 한 다음 멸균수로 1 회 세척 하였다. 이후, 클린벤치 안에서 $1 \%$ 차아염소산나트륨(sodium hypochlorite)에 2 3분간 침지하여 2차 표면살균 후, 멸균수 로 3 회 세척하였다. 실체 현미경 하에서 조직배양용 핀셋과 메스, 그리고 일회용 주사기 $(5 \mathrm{ml})$ 를 이용하여 표면 살균한 재료로부터 분열조직(meristem)을 절취하였다.

\section{분열조직 절취와 캘러스 유도}

분열조직의 절취 부위는 휴면아의 발달단계에 따라 Stage 1, Stage 2, Stage 3의 3단계로 분류하였으며(Fig. 2), 중앙 정 단 분 열조직(apical meristem, $0.4 \sim 0.8 \mathrm{~mm}$ )만을 절취하거나, 측부 분열조직(lateral meristem) 중 한 개 $(0.2 \sim 0.4 \mathrm{~mm})$ 를 선택하거 나, 또는 정단 분열조직과 측부 분열조직을 동시에 절취하 여 $(0.8 \sim 1.2 \mathrm{~mm})$ 절편체로 사용하였는데(Fig. $2 \mathrm{C})$, 이때 분열 조직을 에워싼 포엽을 2 3매 포함하기도 하였다(Fig. 2E). 분열조직 절편체는 휴면아의 발달단계와 절취 부위에 따라 그 크기와 모양이 다양하였다(Fig. 2C-2E). 절편체로부터 캘 러스를 유도하기 위하여 절편체는 배양용기(model 310100, SPL Life Sciences, Korea $)(100 \mathrm{~mm} \times 40 \mathrm{~mm})$ 안에 $50 \mathrm{ml}$ 씩 분주 된 캘러스 유도 배지에 $10 \sim 20$ 개 씩 치상하여 배양하였다. 캘러스 유도 배지는 MS 배지(Murashige and Skoog 1962) $4.4 \mathrm{~g}$, sucrose $30 \mathrm{~g} / \mathrm{L}$, benzyladenine (BA) $3.0 \mathrm{mg} / \mathrm{L}$, 3-indolebutyric acid (IBA) $0.1 \mathrm{mg} / \mathrm{L}$ 을 첨가하여 $\mathrm{pH}$ 를 5.8로 조정한 후, plant agar 7 $\mathrm{g} / \mathrm{L}$ 를 첨가하여 autoclave에서 $121^{\circ} \mathrm{C}$ 로 20 분간 고압 증기 살 균하여 제조하였다. 배양환경은 낮 16 / 밤 8 시간의 광주기 조 건에 온도 $25 \pm 2^{\circ} \mathrm{C}$, 광도 $50 \sim 100 \mu \mathrm{mol} \cdot \mathrm{m}^{-2} \cdot \mathrm{s}^{-1}$ 하에서 16 주 동 안 배양하였으며, 4 8주마다 동일배지에 계대배양 하였다.
(A)

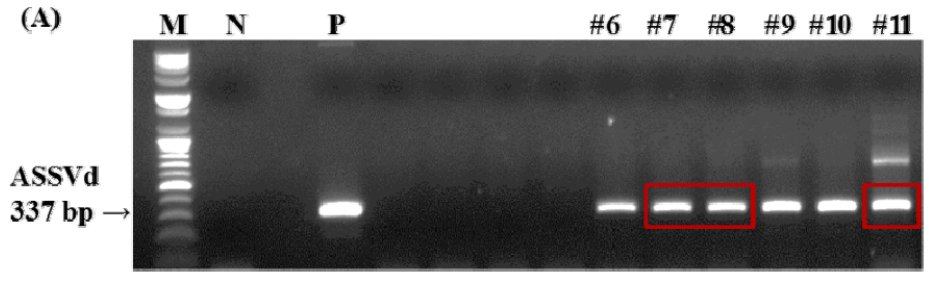

$$
\text { (B) }
$$

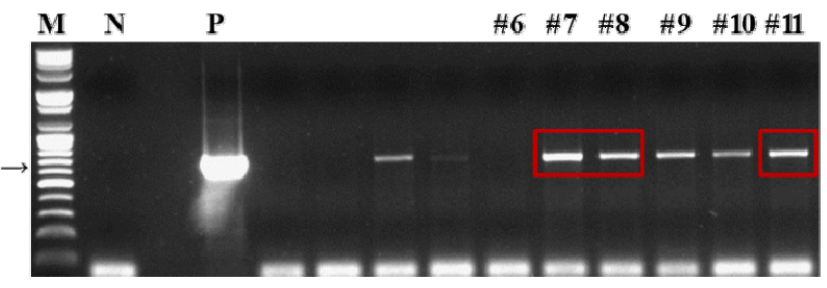

(C)
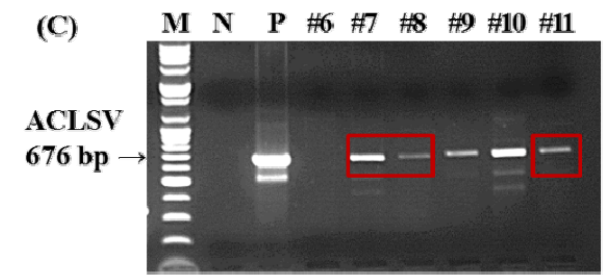

(D)

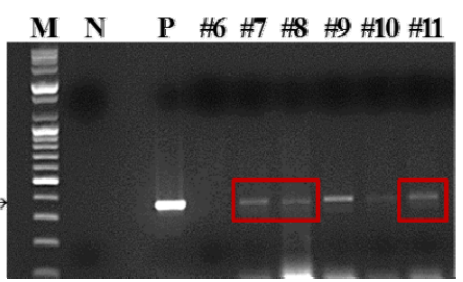

Fig. 1 Virus detection of ASSVd, ASGV, ACLSV and ASPV by RT-PCR in infected 'Hongro' plants before meristem culture. PCR amplification of (A) ASSVd, (B) ASGV, (C) ACLSV and (D) ASPV. M, molecular DNA marker (100 bp); N, negative control; P, positive control; Numbers (\#6 \#11), 'Hongro' plants tested. The plants \#7, \#8 and \#11 were found to be co-infected by ASSVd, ASGV, ACLSV and ASPV, and were used in this study 


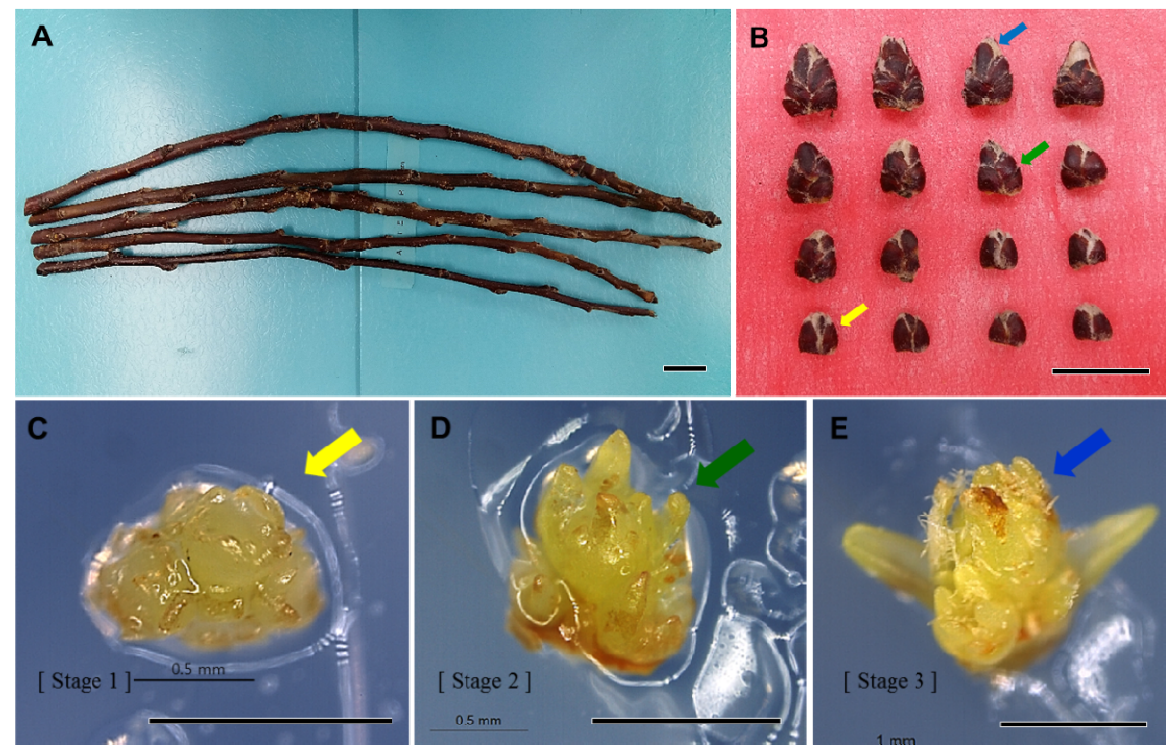

Fig. 2 Meristem excision from dormant buds of apple cultivar Hongro mixed infected by Apple scar skin viroid (ASSVd), Apple chlorotic leaf spot virus (ACLSV), Apple stem pitting virus (ASPV) and Apple stem grooving virus (ASGV). (A) Woody cuttings collected from the field-grown apples during winter (late January). (B) Various sizes and developmental stages of the dormant buds detached. (C) An apical meristem and lateral meristems (hereafter referred to as Stage 1), isolated from the bud indicated by an yellow arrow in (B). (D) More developed an apical meristem and lateral meristems (hereafter referred to as Stage 2) than them in C, isolated from the bud indicated by a green arrow in (B). (E) More developed an apical meristem and lateral meristems (surrounded by bracts, hereafter referred to as Stage 3) than them in D, isolated from the bud indicated by a blue arrow in (B). Scale bars in (A)-(B) = $1 \mathrm{~cm},(\mathrm{C})-(\mathrm{D})=1 \mathrm{~mm}$

Table 1 Primer pairs used in RT-PCR assays for apple virus detection

\begin{tabular}{|c|c|c|c|}
\hline Virus $^{z}$ & Primer sequences $\left(5^{\prime} \rightarrow 3^{\prime}\right)$ & Size (bp) & Reference \\
\hline ASSVd & $\begin{array}{l}\text { Forward : CCCGGTAAACACCGTGCGGT } \\
\text { Reverse : ACCGGGAAACACCTATTGTG }\end{array}$ & 337 & Lee et al. 2001 \\
\hline ASGV & $\begin{array}{l}\text { Forward : ATGAGTTTGGAAGACGTGCTTCAA } \\
\text { Reverse : CTAACCCTCCAGTTCCAAGTTACT }\end{array}$ & 714 & Shim et al. 2004 \\
\hline ACLSV & $\begin{array}{l}\text { Forward : TTCATGGAAAGACAGGGGCAA } \\
\text { Reverse : AAGTCTACAGGCTATTTATTATAAGTCTAA }\end{array}$ & 676 & Menzel et al. 2002 \\
\hline ASPV & $\begin{array}{l}\text { Forwad : ATGTCTGGAACCTCATGCTGC } \\
\text { Reverse : TTGGGATCAACTTTACTAAAAAGCATAAAT }\end{array}$ & 365 & Menzel et al. 2002 \\
\hline $18 \mathrm{~S} \mathrm{rRNA}^{\mathrm{y}}$ & $\begin{array}{l}\text { Forwad : CGCATCATTCAAATATCTGC } \\
\text { Reverse : TTCAGCCTTGCGACCATACT }\end{array}$ & 843 & $\begin{array}{c}\text { Unpublished } \\
\text { (GenBank : DQ341382) }\end{array}$ \\
\hline
\end{tabular}

${ }^{\mathrm{z}} \mathrm{ASSVd}$, Apple scar skin virod; ASGV, Apple stem grooving virus; ACLSV, Apple chlorotic leaf spot virus; ASPV, Apple stem pitting virus

${ }^{\mathrm{y}} 18 \mathrm{~S}$ rRNA, internal control; rRNA, ribosomal RNA

바이러스 제거 효율

ASSVd, ASPV, ACLSV, ASGV 4종의 바이러스가 복합 감염 된 사과 ‘홍로' \#7,\#8,\#11 식물체의 동절기 휴면아로부터 절 취한 분열조직 절편체들은 배양 16 주 후에 분열조직의 발달 단계 따라 절편체의 생존율, 캘러스 형성률, 바이러스 제거 효율을 조사하였다. 캘러스는 RT-PCR에 사용되어야 하므 로 직경 $10 \mathrm{~mm}$ 이상 증식한 계통만 형성률에 포함시켰고, 분 열조직 절편체로부터의 바이러스 제거효율은 직경 $10 \mathrm{~mm}$ 이상의 캘러스를 형성한 절편체 수에 대한, 각 사과 바이러
스의 RT-PCR negative 캘러스를 생산한 절편체 수의 백분율 로 표시하였다.

\section{RNA 추출 및 RT-PCR을 이용한 바이러스 진단}

분석에 사용할 식물 시료 $100 \mathrm{mg}$ 을 CTAB 방법(Gambino et al. 2008)을 변형하여 total RNA를 추출하였으며, 추출된 RNA는 M-MLV reverse transcriptase (Invitrogen, USA)를 이용하여 $\mathrm{cDNA}$ 합성에 사용하였다. $\mathrm{cDNA}$ 를 주형으로 각 바이러스 특이 primer sets (Table 1)를 PCR 반응에 사용하였다. PCR에 
사용한 총 $20 \mu \mathrm{L}$ 의 반응액은 $0.2 \mu \mathrm{M}$ primer $1 \mu \mathrm{L}, 2.5 \mathrm{mM}$ dNTPs $1.6 \mu \mathrm{L}, 5 \mathrm{U}$ TaKaRa Ex Taq polymerase (Takara Bio Inc., Japan) $0.1 \mu \mathrm{L}, 10 \mathrm{X}$ Taq Buffer $2 \mu \mathrm{L}$, cDNA $1 \mu \mathrm{L}$, RNAase-free water $13.3 \mu \mathrm{L}$ 을 혼합하여 사용하였다. PCR 조건은 초기변성 을 위해 $94^{\circ} \mathrm{C}$ 에서 2 분간 반응시킨 뒤, DNA 증폭을 위한 반응 $\left(95^{\circ} \mathrm{C}\right.$ 에서 40 초간 DNA 변성, $60^{\circ} \mathrm{C}$ 에서 30 초간 primer 접합, $72^{\circ} \mathrm{C}$ 에서 30 초간 DNA 신장)을 35 회 반복하였다. 최종 신장 을 위해 $72^{\circ} \mathrm{C}$ 에서 5 분간 반응시킨 후 종료하였으며, $18 \mathrm{~S}$ rRNA를 내부 대조구(internal control) 사용하여 합성 된 cDNA 가 RT-PCR 반응에 제대로 사용되었는지를 확인하였다. 반 응이 증폭된 DNA는 $1.3 \%$ agarose gel 상에서 $100 \mathrm{~V}$ 에서 30 분 간 전기영동 한 후, ethidium bromide로 염색하여 UV 상에서 관찰하였다.

\section{결과 및 고찰}

\section{휴면아의 분열조직 절편체부터의 캘러스 형성}

배지에 치상한 분열조직 절편체들(Fig. $3 \mathrm{~A}-3 \mathrm{C}$ )은 배양 1 주 후부터 녹색으로 변하고, 2 주 차에 3 배 이상 크기가 팽창하 면서 절편체로부터 캘러스가 형성되기 시작하였다(Fig. $3 \mathrm{D}-3 \mathrm{~F})$. 이 후 캘러스가 발달하고 증식하면서(Fig. 3G-3I) 16 주 후에는 직경 $10 \mathrm{~mm}$ 이상 증식한 캘러스(Fig. $3 \mathrm{~J}-3 \mathrm{~L}$ ) 계통이 확보되었으며, 다양한 분열조직 절편체로부터 캘러스가 형 성되었다(Fig. $3 \mathrm{M}-3 \mathrm{~N}$ ). 총 71 개의 분열조직 절편체를 배양한 결과, 배양 16 주 후 절편체의 생존율은 $68.5 \%$ 이었고, 직경 10 $\mathrm{mm}$ 이상의 캘러스 형성률은 $42.5 \%$ 로 31 계통이 확보되었다 (Table 2).

휴면아의 분열조직으로부터 형성된 캘러스에서의 바이러스 제거효율

$\mathrm{ASSVd}, \mathrm{ASPV}, \mathrm{ACLSV}, \mathrm{ASGV}$ 4종의 바이러스가 복합 감염 된 사과 ‘홍로' \#7,\#8,\#11 식물체의 휴면아 분열조직으로부 터 형성된 캘러스 31 계통은 RT-PCR을 2회 이상 수행하여 검 정한 바이러스 밴드가 나타나지 않은 경우를 RT-PCR negative 로 정하고 바이러스 제거를 확인하였다. 휴면아의 분열조직 배양으로 인한 ASSVd 제거는 총 31계통 중 2계통에서 RT-PCR positive, 29계통에서 RT-PCR negative로 나타났고(Fig. 4), ASGV 는 23계통에서 positive, 8계통에서 negative로 확인되었다 (Fig. 5). ACLSV는 positive 계통이 없이 모든 계통이 negative 로 나타났다(Fig. 6). ASPV는 ASSVd와 마찬가지로 31계통 중 2계통에서 positive, 29계통에서 negative로 나타났다(Fig. 7). 결과적으로, 휴면아의 분열조직 배양을 통해 ACLSV의 제 거율은 $100 \%, \mathrm{ASPV}$ 와 $\mathrm{ASSVd}$ 는 $93.5 \%$ 의 높은 제거효율을 보였다(Table 2). 반면, $\mathrm{ASGV}$ 는 캘러스 계통의 $25.8 \%$ 가 제거

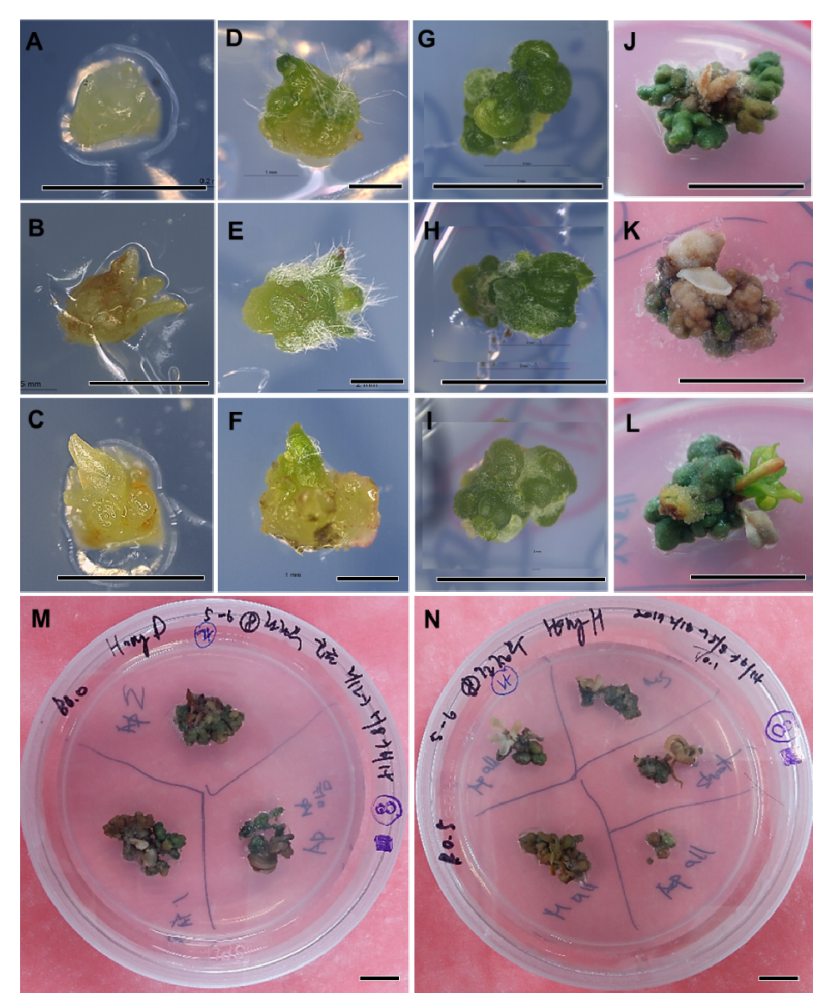

Fig. 3 Examples of callus lines obtained by the meristem culture directly from dormant 'Hongro' buds co-infected by ASSVd, ACLSV, ASPV and ASGV. Various sizes and developmental stages of the apical meristem and the lateral meristems (A-C, described in Fig. 1) cultured on MS medium supplemented with $3 \%$ sucrose, $3.0 \mathrm{mg} / \mathrm{L} \mathrm{BA}$ and $0.1 \mathrm{mg} / \mathrm{L} \mathrm{IBA}$. (A) An apical meristem $(0.4 \mathrm{~mm})$ in Stage 1. (B) An apical meristem $(0.8$ $\mathrm{mm}$ ) in Stage 2. (C) Apical meristem with lateral meristems $(1.0 \mathrm{~mm})$ in Stage 2. (D)-(F) Explants begin to form greenish calli on them after 2-3 weeks from the culture initiation. (G)-(I) calli developed and (J)-(L) proliferated. $(\mathrm{M})-(\mathrm{N})$ Callus lines in culture plates after 16 weeks of culture. Scale bars in (A)-(F) $=1 \mathrm{~mm},(\mathrm{G})-(\mathrm{N})=1 \mathrm{~cm}$

\section{되어 상대적으로 제거효율이 낮았다(Table 2).}

분열조직 배양(meristem culture)은 여러 식물 종에서 바이 러스 제거를 위해 사용되는 방법 중의 하나로 식물체 재생 효율은 배양한 경정의 크기에 비례하나, 바이러스 제거는 그에 반비례하여 경정의 크기가 클수록 제거 효율은 낮아지 는데, 일반적으로 $0.2 \sim 0.4 \mathrm{~mm}$ 크기가 바이러스 제거에 효과 적이라고 하였다(Faccioli and Marani 1998). 그러나, 그러한 작은 크기의 경정만을 절취하여 감염부위를 제거하는 것은 기계적으로 어려운 일이며, $1.0 \mathrm{~mm}$ 이상의 크기에서는 크게 Virus-free 효율이 저하된다고 하였다(Quak 1987; Wang et al. 2008; Wang and Valkonen 2009). Momma and Takahashi T (1983) 는 Hop Stunt Viroid에 감염된 홉(hop) 식물체의 경정배양을 통해 재생된 식물체 중 $0.2 \sim 0.3 \mathrm{~mm}$ 크기의 경정을 사용한 경 우에는 바이로이드가 제거되었지만, $0.4 \mathrm{~mm}$ 이상일 경우에 는 바이로이드가 전혀 제거되지 않았다고 하였다. Plopa and Preda (2013)은 Apple mosaic virus에 감염 된 사과의 세가지 품 
Table 2 Virus elimination efficiency of ASSVd, ASPV, ACLSV and ASGV from callus lines derived from meristem culture directly from dormant buds in apple cultivar Hongro ${ }^{\mathrm{z}}$

\begin{tabular}{|c|c|c|c|c|c|c|c|c|c|}
\hline \multicolumn{2}{|c|}{$\begin{array}{c}\text { Developmental } \\
\text { stages of meristem } \\
\text { explants }^{\mathrm{y}}\end{array}$} & \multirow{5}{*}{$\begin{array}{c}\text { No. of } \\
\text { explants } \\
\text { cultured } \\
\\
20\end{array}$} & \multirow{5}{*}{$\begin{array}{c}\begin{array}{c}\text { Survival } \\
\text { rate } \\
(\%)\end{array} \\
\\
\\
60.0\end{array}$} & \multirow{5}{*}{$\begin{array}{c}\text { Callus } \\
\text { formation } \\
(10 \mathrm{~mm}>)(\%) \\
45.0\end{array}$} & \multirow{5}{*}{$\begin{array}{l}\text { No. of explants } \\
\text { forming callus } \\
(10 \mathrm{~mm}>)(\mathrm{A})\end{array}$} & \multicolumn{2}{|c|}{$\begin{array}{l}\text { No. of explants forming } \\
\text { RT-PCR negative callus } \\
\text { (B) }\end{array}$} & \multicolumn{2}{|c|}{$\begin{array}{l}\text { Virus elimination } \\
\text { efficiency } \\
(\mathrm{B} / \mathrm{A} \%)\end{array}$} \\
\hline \multirow{12}{*}{$\begin{array}{c}\text { Stage } \\
1\end{array}$} & \multirow{4}{*}{$\begin{array}{c}\text { Apical } \\
\text { meristem }\end{array}$} & & & & & ASSVd & 9 & ASSVd & 100 \\
\hline & & & & & & ASGV & 3 & ASGV & 33.3 \\
\hline & & & & & & ACLSV & 9 & ACLSV & 100 \\
\hline & & & & & & ASPV & 9 & ASPV & 100 \\
\hline & \multirow{4}{*}{$\begin{array}{c}\text { Lateral } \\
\text { meristem }\end{array}$} & \multirow{4}{*}{19} & \multirow{4}{*}{31.6} & \multirow{4}{*}{15.8} & \multirow{4}{*}{3} & ASSVd & 3 & ASSVd & 100 \\
\hline & & & & & & ASGV & 1 & ASGV & 33.3 \\
\hline & & & & & & ACLSV & 3 & ACLSV & 100 \\
\hline & & & & & & ASPV & 3 & ASPV & 100 \\
\hline & \multirow{4}{*}{$\begin{array}{c}\text { Apical } \\
\text { meristem }+ \\
\text { lateral } \\
\text { meristems }\end{array}$} & \multirow{4}{*}{7} & \multirow{4}{*}{85.7} & \multirow{4}{*}{71.4} & \multirow{4}{*}{5} & ASSVd & 5 & ASSVd & 100 \\
\hline & & & & & & ASGV & 3 & ASGV & 60.0 \\
\hline & & & & & & ACLSV & 5 & ACLSV & 100 \\
\hline & & & & & & ASPV & 5 & ASPV & 100 \\
\hline \multirow{12}{*}{$\begin{array}{c}\text { Stage } \\
2\end{array}$} & \multirow{4}{*}{$\begin{array}{c}\text { Apical } \\
\text { meristem }\end{array}$} & \multirow{4}{*}{6} & \multirow{4}{*}{83.3} & \multirow{4}{*}{66.7} & \multirow{4}{*}{4} & ASSVd & 3 & ASSVd & 75.0 \\
\hline & & & & & & ASGV & 0 & ASGV & 0 \\
\hline & & & & & & ACLSV & 4 & ACLSV & 100 \\
\hline & & & & & & ASPV & 4 & ASPV & 100 \\
\hline & \multirow{4}{*}{$\begin{array}{c}\text { Lateral } \\
\text { meristem }\end{array}$} & \multirow{4}{*}{14} & \multirow{4}{*}{100} & & & ASSVd & 5 & ASSVd & 83.3 \\
\hline & & & & 120 & 6 & ASGV & 1 & ASGV & 16.7 \\
\hline & & & & 42.9 & 0 & ACLSV & 6 & ACLSV & 100 \\
\hline & & & & & & ASPV & 6 & ASPV & 100 \\
\hline & Anical & & & & & ASSVd & 1 & ASSVd & 100 \\
\hline & meristem + & 3 & 100 & 333 & 1 & ASGV & 0 & ASGV & 0 \\
\hline & lateral & & & & 1 & ACLSV & 1 & ACLSV & 100 \\
\hline & & & & & & ASPV & 1 & ASPV & 100 \\
\hline & Apical & & & & & ASSVd & 3 & ASSVd & 100 \\
\hline Stage & meristem + & & & & & ASGV & 0 & ASGV & 0 \\
\hline 3 & $\begin{array}{c}\text { lateral } \\
\text { meristems }\end{array}$ & 4 & 100 & 75.0 & 3 & ACLSV & 3 & ACLSV & 100 \\
\hline & $2-3$ bracts & & & & & ASPV & 1 & ASPV & 33.3 \\
\hline & & & & & & ASSVd & 29 & ASSVd & 93.5 \\
\hline & Total & 71 & 685 & 12 & 31 & ASGV & 8 & ASGV & 25.8 \\
\hline & Iotal & $/ 1$ & 00.3 & 42.3 & 31 & ACLSV & 31 & ACLSV & 100 \\
\hline & & & & & & ASPV & 29 & ASPV & 93.5 \\
\hline
\end{tabular}

${ }^{\mathrm{z}}$ Hongro co-infected by ASSVd, ASPV, ACLSV and ASGV before meristem culture and the virus elimination efficiency was investigated after 16 weeks from the culture initiation

${ }^{\mathrm{y}}$ Refer to Figure 1

종의 경정배양에서 $0.3 \mathrm{~mm}$ 와 $1.0 \mathrm{~mm}$ 길이의 두 가지 경정을 사용하였을 때, $0.3 \mathrm{~mm}$ 의 경정을 이용한 경우는 식물체에서 감염률이 $50 \sim 58 \%$ 이었고, $1.0 \mathrm{~mm}$ 의 경우에는 $77 \sim 85 \%$ 의 감 염률을 보였다고 하였다.
Li et al. (2016)의 보고에 의하면, ASPV와 ASGV에 복합 감 염된 사과 'M9'과 'M26' 대목의 경정배양에서 $1.0 \mathrm{~mm}$ 길이 의 경정을 사용했을 경우, 신초 재생은 $90 \%$ 정도로 이루어졌 으나 각각의 바이러스는 전혀 제거되지 않아 제거효율이 두 

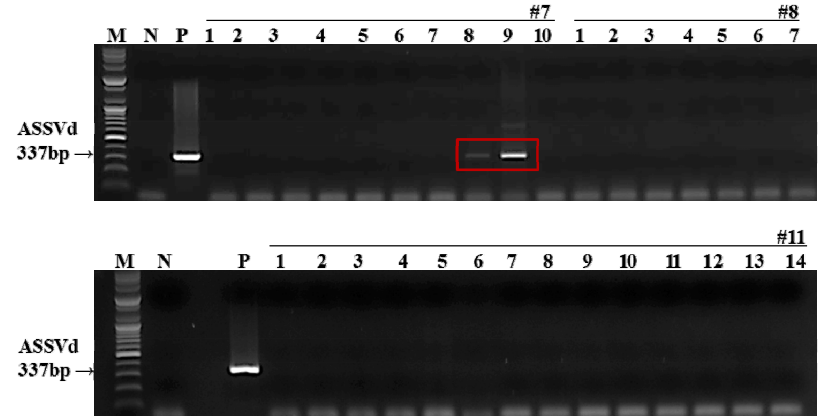

Fig. 4 Virus detection of ASSVd by RT-PCR in callus lines after meristem culture directly from dormant buds of apple 'Hongro'. M, molecular DNA marker (100 bp); N, negative control; P, positive control; Numbers of \#7:1-10, \#8:1-7 and $\# 11: 1-14$, callus lines obtained by meristem culture from the infected dormant buds of \#7, \#8 and \#11, respectively. Amplified bands of the virus were outlined by the red square
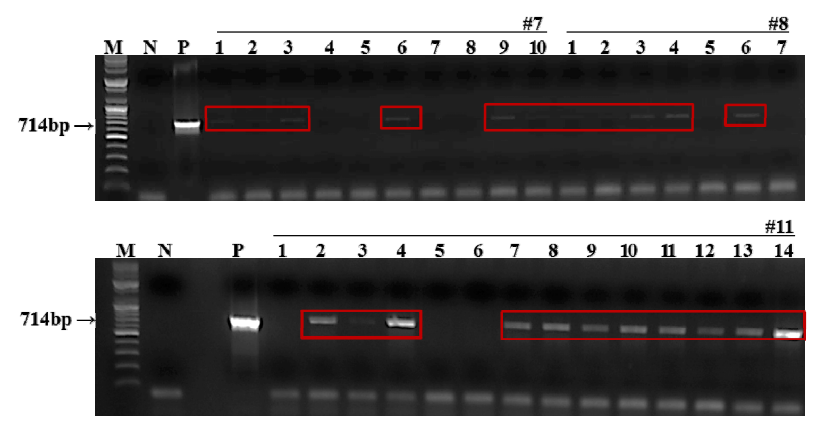

Fig. 5 Virus detection of ASGV by RT-PCR in callus lines after meristem culture directly from dormant buds of apple 'Hongro'. $\mathrm{M}$, molecular DNA marker (100 bp); N, negative control; P, positive control; Numbers of \#7:1-10, \#8:1-7 and \#11:1-14, callus lines obtained by meristem culture from the infected dormant duds of $\# 7$, \#8 and \#11, respectively. The amplified bands of the virus were outlined by the red square

바이러스 모두 $0 \%$ 이었다고 하였다. 또한, $0.5 \mathrm{~mm}$ 의 경정을 사용하였을 때는 $\mathrm{ASPV}$ 는 $10 \%$ 또는 $100 \%$ 가 제거된 반면, $\mathrm{ASGV}$ 는 $1.0 \mathrm{~mm}$ 를 사용했을 때와 마찬가지로 제거율이 $0 \%$ 이었다고 하였다. 본 연구실험의 Table 2 의 결과를 보면, $\mathrm{ACLSV}$ 는 휴면아의 모든 발달단계에서 $0.2 \sim 1.2 \mathrm{~mm}$ 길이의 분열조직을 배양하였을 때 바이러스 제거율은 모두 $100 \%$ 를 나타내었고, ASSVd는 Stage 2의 경정분열조직과 측부 분열 조직만을 각각 단독으로 1 개 배양하였을 때를 제외하곤, $\mathrm{ACLSV}$ 와 마찬가지로 $0.2 \sim 1.2 \mathrm{~mm}$ 길이의 모든 분열조직의 배양으로 인해 대부분 바이러스가 제거되었다(93.5\%). 또 한, $\mathrm{ASPV}$ 는 경정과 측부 분열조직에 포엽(bracts)을 포함하 였을 때 제거율이 저하되었는데, 이 경우를 제외하면 ASPV 도 모든 크기의 분열조직에서 대부분의 바이러스가 제거된 것이다(93.5\%). 비록 본 실험에서 신초 재생을 유도하지는 않았지만, 기존의 보고된 경정분열조직의 크기 보다 큰 크 기인 $0.4 \mathrm{~mm}$ 이상의 분열조직에서도 상기 기술한 세가지 종 류의 바이러스가 휴면아의 발달단계에 크게 영향을 받지 않
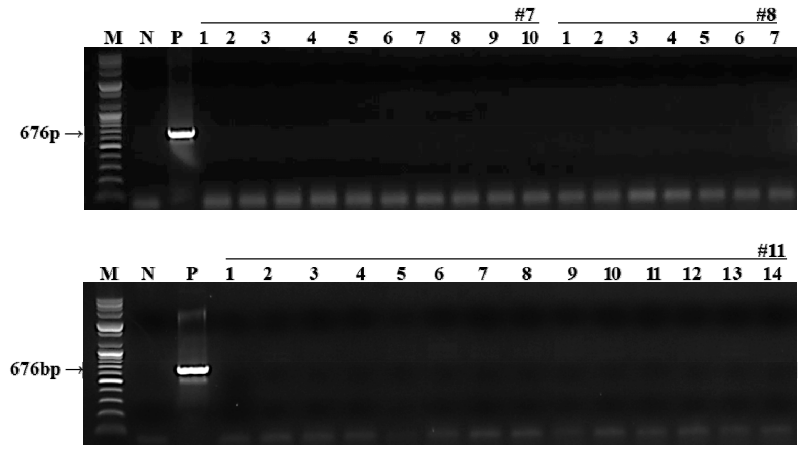

Fig. 6 Virus detection of ACLSV by RT-PCR in callus lines after meristem culture directly from dormant buds of apple 'Hongro'. M, molecular DNA marker (100 bp); N, negative control; P, positive control; Numbers of \#7:1-10, \#8:1-7 and $\# 11: 1-14$, callus lines obtained by meristem culture from infected dormant buds of $\# 7, \# 8$ and $\# 11$, respectively. No amplified bands of the virus were present in all callus lines

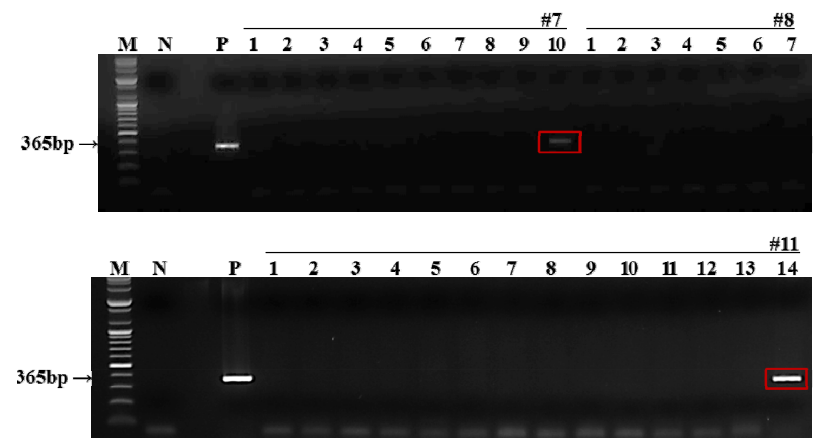

Fig. 7 Virus detection of ASPV by RT-PCR in callus lines after meristem culture directly from dormant buds of apple 'Hongro'. M, molecular DNA marker (100 bp); N, negative control; P, positive control; Numbers of \#7:1-10, \#8:1-7 and \#11:1-14, callus lines obtained by meristem culture from the infected dormant buds of $\# 7, \# 8$ and $\# 11$, respectively. The amplified bands of the virus were outlined by the red square

고 높은 효율로 제거된 것은 상당히 주목할 만한 결과로 판 단된다.

바이러스에 감염된 사과 대목을 기내도입 후 초저온보존 법(cryopreservation)을 이용하면 상기 기술한 경정배양만을 도입하였을 경우와는 달리, $1.0 \mathrm{~mm}$ 이상 크기의 경정배양으 로 재생된 신초에서도 상당히 바이러스가 제거되었다는 보 고와(Li et al. 2016), 복숭아와 배에서 바이로이드 감염 기내 신초를 일정기간 $4^{\circ} \mathrm{C}$ 한냉처리(cold therapy) 한 후 $1 \sim 2 \mathrm{~mm}$ 크기의 경정을 절취하여 비감염 신초를 획득하였다는 보고 (El-Doungdoug et al. 2010)의 결과들을 볼 때 낮은 온도가 정단 분열조직 부위에서 비감염 부위를 증가시키는 것으로 추측 된다. 이러한 결과에 착안하여, 본 연구진은 동절기 휴면아 를 이용하면 경정조직이 이미 자연상태에서 일정기간 한냉 처리를 받은 것이므로 생장중인 신초의 경정을 이용하는 것 보다 바이러스 제거 효율이 높을 것이라는 가설을 세우고 본 실험을 추진하게 되었는데, 본 연구실험의 장점은 기존의 
Table 3 Simultaneous virus elimination of ASSVd, ASPV, ACLSV and ASGV from callus derived from meristem explants based on their developmental stages directly from dormant Hongro buds

\begin{tabular}{|c|c|c|c|c|c|c|c|c|c|c|}
\hline \multirow{2}{*}{\multicolumn{2}{|c|}{$\begin{array}{l}\text { Developmental stages of } \\
\text { meristem explants }{ }^{\mathrm{y}}\end{array}$}} & \multicolumn{4}{|c|}{$\begin{array}{l}\text { No. of callus obtained } \\
(>10 \mathrm{~mm}) \text { from }\end{array}$} & \multicolumn{5}{|c|}{ No. of callus from which each virus was eliminated } \\
\hline & & $\# 7^{\mathrm{z}}$ & $\# 8$ & $\# 11$ & $\begin{array}{l}\text { Sub } \\
\text { total }\end{array}$ & Virus & \#7 & $\# 8$ & $\# 11$ & Sub total \\
\hline \multirow{12}{*}{$\begin{array}{c}\text { Stage } \\
1\end{array}$} & \multirow{4}{*}{ Apical meristem } & \multirow{4}{*}{3} & \multirow{4}{*}{3} & \multirow{4}{*}{3} & \multirow{4}{*}{9} & ASSVd & $3^{y}$ & 3 & 3 & 9 \\
\hline & & & & & & ASGV & 1 & 0 & 2 & 3 \\
\hline & & & & & & ACLSV & 3 & 3 & 3 & 9 \\
\hline & & & & & & ASPV & 3 & 3 & 3 & 9 \\
\hline & \multirow{4}{*}{ Lateral meristem } & \multirow{4}{*}{3} & \multirow{4}{*}{-} & \multirow{4}{*}{-} & \multirow{4}{*}{3} & ASSVd & 3 & - & - & 3 \\
\hline & & & & & & ASGV & 1 & - & - & 1 \\
\hline & & & & & & ACLSV & 3 & - & - & 3 \\
\hline & & & & & & ASPV & 3 & - & - & 3 \\
\hline & \multirow{4}{*}{$\begin{array}{l}\text { Apical meristem }+ \\
\text { lateral meristems }\end{array}$} & \multirow{4}{*}{1} & \multirow{4}{*}{1} & \multirow{4}{*}{3} & \multirow{4}{*}{5} & ASSVd & 1 & 1 & 3 & 5 \\
\hline & & & & & & ASGV & 1 & 1 & 1 & 3 \\
\hline & & & & & & ACLSV & 1 & 1 & 3 & 5 \\
\hline & & & & & & ASPV & 1 & 1 & 3 & 5 \\
\hline \multirow{12}{*}{$\begin{array}{l}\text { Stage } \\
2\end{array}$} & \multirow{4}{*}{ Apical meristem } & \multirow{4}{*}{1} & \multirow{4}{*}{-} & \multirow{4}{*}{3} & \multirow{4}{*}{4} & ASSVd & 0 & - & 3 & 3 \\
\hline & & & & & & ASGV & 0 & - & 0 & 0 \\
\hline & & & & & & ACLSV & 1 & - & 3 & 4 \\
\hline & & & & & & ASPV & 1 & - & 3 & 4 \\
\hline & \multirow{4}{*}{ Lateral meristem } & \multirow{4}{*}{1} & & & & ASSVd & 0 & 1 & 4 & 5 \\
\hline & & & 1 & 4 & 6 & ASGV & 1 & 0 & 0 & 1 \\
\hline & & & 1 & 4 & 0 & ACLSV & 1 & 1 & 4 & 6 \\
\hline & & & & & & ASPV & 1 & 1 & 4 & 6 \\
\hline & & & & & & ASSVd & - & 1 & - & 1 \\
\hline & Apical meristem + & & 1 & & 1 & ASGV & - & 0 & - & 0 \\
\hline & lateral meristems & - & 1 & - & 1 & ACLSV & - & 1 & - & 1 \\
\hline & & & & & & ASPV & - & 1 & - & 1 \\
\hline & & & & & & ASSVd & 1 & 1 & 1 & 3 \\
\hline Stage & Apical meristem + & 1 & 1 & 1 & 3 & ASGV & 0 & 0 & 0 & 0 \\
\hline 3 & $\begin{array}{l}\text { bracts } \\
\text { bots }\end{array}$ & 1 & 1 & 1 & 3 & ACLSV & 1 & 1 & 1 & 3 \\
\hline & & & & & & ASPV & 0 & 1 & 0 & 1 \\
\hline & & & & & & ASSVd & 8 & 7 & 14 & 29 \\
\hline & Total & 10 & 7 & 14 & 31 & ASGV & 4 & 1 & 3 & 8 \\
\hline & Tutal & 10 & 1 & 14 & נI & ACLSV & 10 & 7 & 14 & 31 \\
\hline & & & & & & ASPV & 9 & 7 & 13 & 29 \\
\hline
\end{tabular}

${ }^{\mathrm{z}}$ Name of Hongro plant co-infected by ASSVd, ASPV, ACLSV and ASGV before meristem culture

${ }^{\mathrm{y}}$ Bold characters mean ASSVd, ASPV, ACLSV and ASGV were eliminated simultaneously

연구들과는 달리 감염 식물체의 기내도입이나 별도의 인위 적인 무병화 처리 과정을 생략할 수 있다는 것이다. 본 실험 에 사용한 휴면아의 분열조직이 꽃눈일 가능성은 있으나, 본 결과의 내용을 바탕으로 분열조직 배양배지의 호르몬 조 성을 변경하여 신초를 유도한다면 단순히 휴면아의 분열조
직 배양만으로 사과에서 바이러스 무병주 생산이 가능할 것 으로 여겨진다.

본 연구에서 휴면아의 경정 분열조직을 사용하게 된 또 하 나의 착안점은 식물체내에서의 바이러스의 이동은 광합성 산물의 이동과 동일하다는 점인데, 물론 도관이 아직 분화 
화지 않은 윗부분인 생장점 부위는 바이러스를 포함하지 않 을 것이라고 알려져 있지만(Grout BWW 1999), 지금까지 정 단 분열조직의 바이러스 비감염 부위와 식물의 광합성 산물 이동 경로를 연관하여 언급한 적은 없었다. 식물 RNA 바이 러스가 식물체 전역으로 이동하는 경로는 식물체의 체관을 통하여, 즉 식물의 동화산물 이동경로와 동일하다(Leisner and Turgeon 1993)고 알려져 있다. 본 실험에 사용한 동절기 휴면아는 광합성을 하지 않는 상태로서 동화산물의 이동이 없을 것이고, 동화산물의 이동이 없다는 것은 그 만큼 동화 산물의 통로가 되는 조직이 분화하지 않았을 것이다. 따라 서, 바이러스가 식물체 존재하기는 하나, 정체되어 있게 되 므로 식물체내에서 비감염 부위는 그 범위가 식물체가 생장 중일 때보다 넓을 것이라고 추측하였다. 본 연구진은 당해 년 8월에 실험에 사용하였던 동일 감염주의 나뭇가지에 있 는 액아의 분열조직을 살펴보았는데 그 크기가 실험에 사용 했던 동절기 분열조직 크기보다 훨씬 작은 것을 관찰할 수가 있었다(자료 미제시). 그러므로, 본 연구 실험에 사용한 동절 기 휴면아는 비 광합성 상태에서 그 내부의 분열조직이 자연 적으로 한냉처리된 것으로, 바이러스 비감염 부위 적출을 위한 최적의 식물 재료라고 할 수 있을 것이다.

본 연구 실험 결과에서 $\mathrm{ASGV}$ 가 다른 바이러스 제거효율 에 비해 상대적으로 $25.8 \%$ 의낮은 제거효율을 보인 것과, $\mathrm{Li}$ et al. (2016)이 초저온보존법을 병행한 경정배양을 통해서도 $\mathrm{ASGV}$ 가 전혀 제거되지 않은 점은 $\mathrm{ASGV}$ 가 경정분열 조직 내에 존재한다는 것을 의미하는데, 실제로 immunolocalization 분석을 통해 경정분열 조직 내에서 그 존재가 확인되었다 $(\mathrm{Li}$ et al. 2016). 그럼에도 불구하고, 본 실험결과의 Table 1을 보 면 Stage 1 단계의 휴면아에서 절취한 분열조직에서 $\mathrm{ASGV}$ 가 약 $40 \%$ 제거된 것을 볼 수 있는데, 이러한 효율은 상기 기 술한 기존의 보고(Li et al. 2016)와 대조해 볼 때 상대적으로 상당히 효과적이라고 볼 수 있다. Table 2에서 보듯이, 감염 되었던 4종의 모든 바이러스가 제거된 캘러스(총 31 계통 캘 러스 중 7 계통)를 생산한 분열조직 절편체의 발달단계를 확 인한 결과, Stage 1 의 휴면아에서만 절취된 것으로 나타났는 데, 그 원인은 $\mathrm{ASGV}$ 가 이 단계에서만 주로 제거되었기 때문 이었다. 그러므로, 많은 종류의 바이러스를 효과적으로 제 거하기 위해서는 발달단계가 어린 분열조직을 사용하는 것 이 바람직할 것으로 보인다.

본 연구는 사과 ‘홍로' 에서 휴면아의 분열조직을 배양하 여 바이러스가 제거됨을 보여주었는데, 차후 다른 사과 품 종이나, 또는, 다른 과종에도 적용하여 실험 결과들을 대조 해 볼 필요가 있다. 본 연구결과는 아직 세계적으로 보고된 바가 없는 것으로서, 향 후 사과를 포함한 과수의 무병묘 생 산에 매우 유용한 자료로 활용될 수 있을 것으로 전망된다.

\section{적 요}

Apple scar skin viroid (ASSVd), Apple chlorotic leaf spot virus (ACLSV), Apple stem pitting virus (ASPV), Apple stem grooving virus (ASGV)는 사과를 감염시키는 대표적인 바이러스로, 이러한 4종 바이러스에 복합 감염된 사과 '홍로'의 동절기 가지의 휴면아(측아)로부터 다양한 크기 $(0.4 \mathrm{~mm} \sim 1.2 \mathrm{~mm})$ 와 발달단계 (이하 Stage 1, Stage 2, Stage 3라 칭함)의 경정 및 측부 분열조직을 절취하여 $\mathrm{BA} 3.0 \mathrm{mg} / \mathrm{L}$ 와 $\mathrm{IBA} 0.1 \mathrm{mg} / \mathrm{L}$ 가 혼 합된 배지에 배양하여 캘러스를 형성시킨 후, 감염 바이러 스바이러스의 제거유무를 조사하였다. 직경 $10 \mathrm{~mm}$ 이상 증 식된 캘러스 31 계통을 RT-PCR 분석으로 제거효율을 알아 본 결과, $\mathrm{ACLSV}$ 는 $100 \%, \mathrm{ASSVd}$ 와 $\mathrm{ASPV}$ 는 $93.5 \%$ 의 높은 제 거 효율을 보인 반면, $\mathrm{ASGV}$ 는 $25.8 \%$ 로 상대적으로 제거효 율이 낮았다. 4 종 바이러스가 동시에 모두 제거되는 경우는 Stage 1 의 휴면아의 분열조직을 배양하였을 때만 가능하였 는데, 그 이유는 ASGV가 이 시기의 배양에서 주로 제거되었 기 때문으로, $\mathrm{ASGV}$ 는 다른 바이러스와는 달리 분열조직의 발달단계가 큰 영향을 미치는 것으로 나타났다. 휴면아의 분열조직을 배양하여 바이러스를 제거한 예는 세계적으로 보고된 바가 없는 것으로서, 본 연구결과는 향 후 사과의 무 병묘 생산에 매우 유용한 자료로 활용될 것이다.

\section{사 사}

본 연구는 농촌진흥청 연구과제(세부과제번호:PJ0102280 62017)의 지원에 의해 이루어진 것임.

\section{References}

Chen W, Tien P, Lin LP, Wang GP, Liu FC (1986) Study of viroid RNA isolated from apple scar skin diseased tissues. Chin J Virol 2:366-371

El-Doungdoug KA, Osman ME, Abdelkader HS, Dawoud RA, Elbaz RM (2010) Elimination of Hop Stund Viroid (HSVd) from infected each and pear plants using cold therapy and chemotherapy. Aust J Basic Appl Sci 4:54-60

Faccioli VC and Marani F (1998) Virus elimination by meristem tip culture and tip micrografting. In plant virus disease control. Hadidi A et al. (eds). American Phytopathological Society. pp. 346-380

Gambino G, Perrone I, Gribaudo, I (2008) A rapid and effective method for RNA extraction from different tissues of grapevine and other woody plants. Phytochem Anal 19:520-525

Grout BWW (1999) Meristem-tip culture for propagation and virus elimination. In: Hall RD (ed.). Methods in molecular biology. vol 111. Human Press Inc. Totowa, NJ. pp. 115-125 
Hansen A, Lane W (1985) Elimination of apple chlorotic leaf spot virus from apple shoot cultures by ribavirin. Plant Dis 69: 134-135

Hu G, Dong Y, Zhang Z, Fan X, Ren F, Zhou J (2015) Virus elimination from in vitro apple by thermotherapy combined with chemotherapy. Plant Cell Tiss Cult 121:435-443

Kim DH, Kim HR, Heo S, Kim SH, Kim M, Shin IS, Kim JH, Cho KH, Hwang JH (2010) Occurrence of Apple scar skin viroid and relative quantity analysis using real-time RT-PCR. Res Plant Dis 16: 247-253

Kwon MJ, Hwang SL, Lee SJ, Lee DH, Lee JY (2002) Detection and distribution of the Apple scar skin viroid-Korean strain (ASSVd-K) from apples cultivated in Korea. J Plant Pathol 18: 342-344

Lee G, Kim JH, Kim HR, Shin IS, Cho KH, Kim SH, Shin J, Kim DH (2013) Production system of virus-free apple plants using heat treatment and shoot tip culture. Res Plant Dis 19: 288-293

Lee JH, Park JK, Lee DH, Uhm JY, Ghim SY, Lee JY (2001) Occurrence of Apple scar skin viroid-Korean strain (ASSVd-K) in apples cultivated in Korea. Plant Pathol J 17:300-304

Leisner SM, Turgeon R (1993) Movement of virus and photoassimilate in the phloem: a comparative analysis. BioEssays 15:741-748

Li BQ, Feng CH, Hu LY, Wang MR, Wang QC (2016) Shoot tip culture and cryopreservation for eradication of Apple stem pitting virus (ASPV) and Apple stem grooving virus (ASGV) from apple rootstocks 'M9' and 'M26'. Ann Appl Biol 168:142-150

Menzel W, Jelkmann W, Maiss E (2002) Detection of four apple viruses by multiplex RT-PCR assays with coamplification of plant mRNA as internal control. J Virol Methods 99:81-92

Momma T, Takahashi T (1983) Cytopathology of shoot apical meristem of hop plants infected with Hop Stunt Viroid. Phytopath Z 106; 272-280

Murashige T, Skoog F (1962) A revised medium for rapid growth and bioassay with tobacco tissue cultures. Phyiol Plant 15:473-497

Paprstien F, Sedlak J, Polak J, Svobodova L, Hanssan M, Bryxiova M (2008) Results of in vitro thermotherapy of apple cultivars. Plant Cell Tiss Cult 94:347-352

Plopa C, Preda S (2013) Elimination of Apple mosaic virus by tissue culture of some infected apple cultivars. Acta Hortic 981:517522

Quak F (1987) Therapy of individual plants. In: Viruses of potatoes and seed-potato production. De Bokx JA and van der Want JPH (eds). Wageningen, Pudoc. pp. 151-161

Shim H, Min Y, Hong S, Kwon M, Kim D, Kim H, Choi Y, Lee S, Yang J (2004) Nucleotide sequences of a Korean isolate of Apple stem grooving virus associated with Black necrotic leaf spot disease on pear (Pyrus pyrifolia). Mol Cells 2:192-199

Ushirozawa K, Tojo Y, Takemae S, Sekiguchi A (1968) Studies on apple scar skin disease. 1. On transmission experiments. Bul Nagano Hort Expt Res Stn 7:1-12

Wang QC, Cuellar WJ, Rajamaki ML, Hirata YM, Valkonen JPT (2008) Combined thermotherapy and cryotherapy for efficient virus eradication: relation of virus distribution, subcellular changes, cell survival and viral RNA degradation in shoot tips. Mol plant Pathol 9:237-250

Wang QC, Valkonen JPT (2009) Cryotherapy of shoot tips: novel pathogen eradication method. Trends Plant Sci 14:119-122 